ISSN 0258-7122 (Print), 2408-8293 (Online)

Bangladesh J. Agril. Res. 41(4): 583-597, December 2016

\title{
BIO-RATIONAL MANAGEMENT OF WHITEFLY (Bemisia tabaci) FOR SUPPRESSING TOMATO YELLOW LEAF CURL VIRUS
}

\author{
M. M. ALAM ${ }^{1}$, M. N. ISLAM ${ }^{2}$, M. Z. HAQUE ${ }^{3}$ \\ R. HUMAYUN ${ }^{4}$ AND K. M. KHALEQUZZAMAN ${ }^{5}$
}

\begin{abstract}
Whitefly (Bemisia tabaci) is the vector of tomato yellow leaf curl virus (TYLCV), is a serious pest of vegetables and other crops worldwide. The experiment was conducted at Bangladesh Agricultural Research institute (BARI) during two consecutive years of 2009 and 2010 to select a suitable bio-rational management practice against white fly, transmitting TYLCV. Treatments comprising tomato variety Ratan with diseased plant uprooting, spraying admire, applying admire on trap crop (marigold), spraying neem, sesame and mustard oil with trix and the untreated control were used in this experiment. The variety Opurba with similar materials as described above was used. Percent virus infected tomato plants ranged from 1.33 to 19.00 in two consecutive years, where the highest infection was recorded in control plot with variety Opurba and the lowest was recorded in variety Ratan treated with Admire. Consequently, the highest yield (47.70 and $52.36 \mathrm{tha}^{-1}$ in $1^{\text {st }}$ and $2^{\text {nd }}$ year, respectively) in the plots of variety Ratan treated with admire and the lowest yield was recorded in untreated control plots with variety Opurba (14.75 and $\left.30.30 \mathrm{t} \mathrm{ha}^{-1}\right)$ for the two consecutive years. A strong positive correlation was observed between whitefly population and \% TYLCV infection for both the years and both varieties of tomato. While a negative correlation was observed between \% TYLCV infection with number of fruits plants ${ }^{-1}$ and yield $\left(\mathrm{t} \mathrm{ha}^{-1}\right)$ for both the years and in both varieties of tomato. These results are consistent with the occurrences of TYLCV, which have been associated with the percent virus infection in relation to yield and yield contributing characters of tomato.
\end{abstract}

Keywords: Disease, management, tomato, tomato yellow leaf curl virus (TYLCV) and white fly

\section{Introduction}

Tomato (Lycopersicon esculentum Mill.) is one of the most popular and widely grown vegetable crops of both tropics and subtropics of the world, belonging to the family Solanaceae. Tomato fruit is considered to be fairly high in vitamins A and $\mathrm{C}$, having high cash value with potential for value-added processing.

${ }^{1 \& 2}$ Senior Scientific Officer \& Scientific Officer, Plant Pathology Division, Bangladesh Agricultural Research Institute (BARI), Joydebpur, Gazipur-1701, ${ }^{3}$ Senior Scientific Officer, Tuber Crop Research Centre (TCRC), BARI, Joydebpur, Gazipur-1701, ${ }^{4}$ Scientific Officer, Plant Pathology Section, RARS, BARI, Ishurdi, Pabna, ${ }^{5}$ Senior Scientific Officer, Spices Research Centre (SRC), BARI, Shibgonj, Bogra, Bangladesh. 
Recently, more emphasis has been given on tomato production not only as a source of vitamins, but also as a source of income and food security. The low yields of tomato are owing to (1) lack of improved varieties; (2) poor fruit set due to excessive rains and temperatures, and (3) insect pest and disease incidence. Viral diseases have been the most important constraint among tomato diseases (Varela, 1995). Its production is seriously hampered by tomato yellow leaf curl virus (TYLCV) with recorded yield loss of $93.95 \%$ (Gupta, 2000).

The TYLCV is a disease that threatens both commercial tomato production in the field and kitchen gardens (Polston et al., 1999). Management techniques are dependent upon the ecology of the virus. The TYLCV is transmitted in a persistent manner by adult whiteflies (Bemisia tabaci) of the Family Aleyrodidae (Brown and Bird, 1995.). This virus has one of the largest described host ranges for Begomovirus and is capable of infecting more than 30 species in over 12 plant families. TYLCV can produce severe symptoms in tomato, it is also able to establish symptomless infections in both wild and non tomato crop species. Despite the lack of TYLCV-induced disease symptoms whiteflies were able to acquire TYLCV from infected pepper plants and transmit it to tomato (Polston et al., 2006). The symptomless but infected pepper plants can serve as virus reservoir for the acquisition and transmission of TYLCV. Other asymptomatic hosts of TYLCV may act as reservoirs in a similar manner. The whitefly has a very large number of hosts upon which it can feed and reproduce. Reservoirs of the vector may also vary among the tomato production regions. Although some resistant cultivars produce an acceptable yield after TYLCV infection by supporting viral replication and can act as TYLCV reservoirs for susceptible crops (Lapidot et al., 2001).

Occurrence of whitefly is very common in winter tomatoes in Bangladesh. But in recent years the problem has increased manifold. So far, no effective management package or resistant variety is available to combat dissemination of TYLCV by whitefly. Therefore, developing a sound and effective management package (s) for whitefly is urgently needed. Identification and characterization of virus infected specific geographical area are important prior to develop sustainable, environment-friendly disease management programs. Farmers commonly use insecticides to control the whitefly for the management of TYLCV. But sole dependence on insecticides causes environmental pollution and pesticide resistance and health hazards. Therefore, it is necessary to search for eco-friendly alternative packages for the management of TYLCV. Oils of plant origin have been reported for the reduction of white fly infestation (Sastry, 1989; Butler et al., 1991; Csizinsky et al., 1997). Accordingly, the present study was designed to improve both the quality and quantity of tomato production through sustainable and eco-friendly management of whitefly and TYLCV in Bangladesh. 


\section{Materials and Method}

The experiment was conducted in the field of RARS, Ishwardi, Pabna during the rabi seasons of 2009 and 2010. Tomato varieties, Ratan (BARI tomato-2) and Opurba (BARI tomato-7) were used in this study. The seeds were sown on October (2009 and 2010) and one month old seedlings were transplanted on November (2009 and 2010). Five sprays with proposed treatments were done at 10 days intervals. Spraying was initiated at 30 days after transplanting when disease symptom was observed in the field. Irrigation, staking and other cultural practices were performed as described by Mondal et al., 2014.

\section{Design of experiment}

The treatments were laid out in a Randomized Complete Block Design with 3 replications. The whole area of experimental field was divided into 3 blocks and each block was again divided into 14 unit plots. The unit plot size was $3 \mathrm{~m}$ x $2 \mathrm{~m}$ and spacing was $60 \mathrm{~cm}$ x $50 \mathrm{~cm}$. Block to block and plot-to-plot distance was $1 \mathrm{~m}$ and $1 \mathrm{~m}$.

\section{Treatments}

Treatments comprising tomato variety Ratan with diseased plant uprooting, spraying Admire $(0.05 \%)$, applying Admire $(0.05 \%)$ on marigold (trap crop), spraying neem oil $(0.5 \%)$ with Trix $(0.5 \%)$, applying sesame oil $(0.5 \%)$ with Trix $(0.5 \%)$, spraying mustard oil $(0.5 \%)$ with Trix $0.5 \%$ and untreated control were used in this experiment. Variety Opurba with similar treatments as described above were used.

\section{Effectiveness of treatments on whitefly and virus-transmission}

The sampling on the incidence of whitefly and the occurrence of TYLCV diseases were done by direct visual method (Hirano et al., 1993). The sampling on the incidence of whitefly was taken at vegetative, early flowering, early fruiting and fruit ripening stages at 15 days interval. The plants were checked visually for the presence of whitefly. Sometimes plants were shaken gently to observe their presence and count their number using tally counter. As the population of whitefly was very low, the number was recorded per 5 plants. Sampling on whitefly incidence was taken at both pre and post application of treatments. Two post treatment counts were taken at each vegetative, early flowering, early fruiting and at fruit ripening stages. The effectiveness of each treatment on reducing the whitefly infestation and suppression of the virus infection was evaluated on the basis of some pre selected parameters. 


\section{TYLCV incidence and spread}

Firstly, the number of plants expressing TYLCV symptoms was recorded at different growth stages of tomato, i.e. vegetative stage, flowering stage and fruiting stage from each treated including the untreated control plot. Spread of viral infection was determined in space and time by measuring the distance between old and new infections in relation to the time interval between detection of first symptoms and subsequent symptoms, in the field (Raccah, 1986). Diseased plants were uprooted from all the treatments except control treatment. The disease was identified mainly through visual observation of typical symptoms of TYLCV like upward curling and cupping of the leaf, with or without marginal chlorosis, smaller leaflets and stunting growth of the plant. Identification of the virus disease was done mainly through visual observation of typical symptoms of TYLCV infection like upward curling, cupping of leaf, with or without marginal chlorosis, smaller leaflets and stunting growth of the plant (Green and Kalloo, 1994 and Sinistera et al., 2000).

Number of infected plant was counted from total plants per plot and percent plant infection by TYLCV was calculated using following formula:

$\%$ TYLCV infected plant $=\frac{\text { Number of TYLCV infected plant }}{\text { Number of total plantsobserved }} \times 100$

\section{Data collection and calculation}

For data collection five plants plot $^{-1}$ were randomly selected and tagged. Data collection was started at 15 days after transplanting (15 DAT) seedlings and continued up to fruit set. All the data were collected once in a week. The data were collected on number of whitefly plant $^{-1}$; number of tomato yellow leaf curl infected plants plot $^{-1}$, number of bunches plant ${ }^{-1}$, number of fruits plant $^{-1}$ and yield $\left(\mathrm{t} \mathrm{ha}{ }^{-1}\right)$.

\section{Yield records}

Mature fruits were harvested weekly and weight was measured using weighing balance $(1 \mathrm{~g}-10 \mathrm{~kg})$, yield was determined plot $^{-1}$. Number of fruits harvested treatment ${ }^{-1}$, total yield and marketable fruit weight were recorded. Fruits were considered marketable when fruits were full grown and had no sign of damage or rot.

\section{Data analysis}

Data were analyzed following ANOVA. Linear regression and Pearson correlations were performed using MS-excel and MSTAT-C statistical programmes. Duncan's Multiple Range Test was also used to separate the means. 
F-distribution values were used to determine significance of differences between those effects (Mead and Curnow, 1990).

\section{Results and Discussion}

\section{A. Results}

\section{Effects of different treatments on white fly population plant $^{-1}$}

White fly population was sharply reduced in the treated plot due to different treatment as compared to the untreated control plot (Table 1). Significantly higher white fly population in $1^{\text {st }}$ year trial was 23.23 (Ratan) and 24.33 (Opurba) in the untreated control plot was recorded, while it was ranged from 2.83 to 18.23 among the treated plots (Table 1). Tomato variety Ratan with Admire treated plot showed the lowest white fly population. In the $2^{\text {nd }}$ year trial, 1.66 to 11.33 virus infected plants were observed in the treated plots where in untreated control plot showed 20.33 (Ratan) and 26.34 (Opurba) white fly population (Table 1). However, Admire sprayed on tomato plants as well as Admire sprayed on the trap crop (marigold) also showed the lowest level of white fly population in both the years and the variety. While the neem oil sprayed plot showed the lowest white fly population among the three oils were used (Table 1).

\section{Effects of different treatments on percent virus infected plants}

Percent virus infected plants was sharply decreased in the treated plots as compared to the untreated control plot (Table 1). The percent virus infected plant in $1^{\text {st }}$ year trial was $14.67 \%$ (Ratan) and $17.33 \%$ (Opurba) was observed in the untreated control plot which was ranged from $4.00 \%$ to $10.67 \%$ among the treated plots (Table 1). Tomato variety Ratan sprayed with Admire showed the 1owest TYLCV infection. In the $2^{\text {nd }}$ year trial, 1.33 to $10.67 \%$ TYLCV infected plants were recorded in the treated plots while in untreated control plot showed 9.33\% (Ratan) and $19.00 \%$ (Opurba) virus infected plants (Table 1). However, Admire treated on tomato varieties as well as on the trap crop (marigold) showed the lowest virus infected plant in both the year and variety. While the neem oil treated plot showed the lowest level of virus infection among the three oils tested (Table 1).

\section{Effects of different treatments on plant height}

The plant height of tomato was significantly accelerated by the application of different treatments consisting of spraying insecticide, oils and uprooting of diseased plant in both years (Table 2). In the $1^{\text {st }}$ year trial the plant height of tomato seedling was ranged from $53.00-55.00 \mathrm{~cm}$ (Ratan) and that of Opurba $86.33-96.00 \mathrm{~cm}$ among the treated plots where as it was $46.33 \mathrm{~cm}$ (Ratan) and $86.00 \mathrm{~cm}$ (Opurba) in the untreated control plots (Table 2). Higher plant height of tomato plants in $2^{\text {nd }}$ year trial, ranging from 82.47 to $102.9 \mathrm{~cm}$ was recorded from 
the treated plots in respect of variety and the lowest plant height, $73.93 \mathrm{~cm}$ (Ratan) and $81.40 \mathrm{~cm}$ (Opurba) were observed in untreated control plot (Table 2). In this study significantly the highest plant height was recorded in Admire sprayed plot, although admire showed some adverse effect on plant growth and accordingly the whitefly population plant ${ }^{-1}$ was minimum in this treatment for both the varieties and years.

Table 1. Effect of tomato variety and different treatments on white fly population and virus infected plants of tomato

\begin{tabular}{l|c|c|c|c}
\hline \multirow{2}{*}{\multicolumn{1}{c}{ Variety x Treatment }} & \multicolumn{2}{c|}{$\begin{array}{c}\text { White fly population } \\
\text { plant }\end{array}$} & \multicolumn{2}{c}{$\begin{array}{c}\text { \% of virus infected } \\
\text { plants }\end{array}$} \\
\cline { 2 - 5 } & $1^{\text {st }}$ year & $2^{\text {nd }}$ year & $1^{\text {st }}$ year & $2^{\text {nd }}$ year \\
\hline Ratan x Uprooting & $18.23 \mathrm{~b}$ & $19.33 \mathrm{~b}$ & $6.67 \mathrm{bcd}$ & $5.50 \mathrm{~cd}$ \\
Ratan x Admire $(0.05 \%)$ & $2.86 \mathrm{e}$ & $2.66 \mathrm{e}$ & $4.00 \mathrm{~d}$ & $1.333 \mathrm{f}$ \\
Ratan x Admire $(0.05 \%)$ on marigold & $2.83 \mathrm{e}$ & $4.33 \mathrm{~d}$ & $5.33 \mathrm{~cd}$ & $2.723 \mathrm{ef}$ \\
Ratan x Neem oil $(0.5 \%)$ & $4.23 \mathrm{de}$ & $5.33 \mathrm{~cd}$ & $5.33 \mathrm{~cd}$ & $2.783 \mathrm{ef}$ \\
Ratan x Sesame oil $(0.5 \%)$ & $5.66 \mathrm{~d}$ & $5.66 \mathrm{~cd}$ & $10.67 \mathrm{~b}$ & $5.333 \mathrm{~cd}$ \\
Ratan x Mustard oil $(0.5 \%)$ & $6.43 \mathrm{c}$ & $6.33 \mathrm{c}$ & $9.33 \mathrm{bc}$ & $4.000 \mathrm{de}$ \\
Ratan X control & $23.23 \mathrm{a}$ & $20.33 \mathrm{~b}$ & $14.67 \mathrm{a}$ & $9.333 \mathrm{~b}$ \\
Opurba x Uprooting & $19.36 \mathrm{~b}$ & $18.23 \mathrm{~b}$ & $9.33 \mathrm{bc}$ & $10.67 \mathrm{~b}$ \\
Opurba x Admire $(0.05 \%)$ & $4.00 \mathrm{~d}$ & $1.66 \mathrm{e}$ & $4.00 \mathrm{~d}$ & $4.000 \mathrm{de}$ \\
Opurba x Admire(0.05\%) on marigold & $4.00 \mathrm{~d}$ & $3.83 \mathrm{~d}$ & $6.67 \mathrm{bcd}$ & $6.667 \mathrm{c}$ \\
Opurba x Neem oil $(0.5 \%)$ & $4.33 \mathrm{~cd}$ & $3.86 \mathrm{~d}$ & $5.33 \mathrm{~cd}$ & $5.333 \mathrm{~cd}$ \\
Opurba x Sesame oil (0.5\%) & $5.33 \mathrm{~cd}$ & $5.23 \mathrm{~cd}$ & $9.33 \mathrm{bc}$ & $9.563 \mathrm{~b}$ \\
Opurba x Mustard oil (0.5\%) & $5.99 \mathrm{c}$ & $5.46 \mathrm{~cd}$ & $9.33 \mathrm{bc}$ & $10.67 \mathrm{~b}$ \\
Opurba x control & $24.33 \mathrm{a}$ & $26.34 \mathrm{a}$ & $17.33 \mathrm{a}$ & $19.00 \mathrm{a}$ \\
CV(\%) & 12.82 & 13.63 & 8.83 & 15.77 \\
\hline
\end{tabular}

In a column, similar letter (s) do not differ significantly by DMRT at 5\% level of probability, 1 st year $=2009$ and 2 nd year $=2010$.

\section{Effects of different treatments on number of branches plant ${ }^{-1}$}

The number of branches plant ${ }^{-1}$ was not significantly increased by the application of different treatments compared to untreated control incase of variety Ratan in $1^{\text {st }}$ year. Numercally, the number of branches was increased up to 5.77 (Ratan) and 7.43 (Opurba) by the application of different treatment while number of branches was 4.87 (Ratan) and 6.10 (Opurba) of the $1^{\text {st }}$ year trial (Table 2) in untreated control plot. The treated plots gave numerically number of branches plant $^{-1}$ of 4.88 to 5.77 (Ratan) and 6.33 to 7.88 (Opurba) in the $2^{\text {nd }}$ year trial and the lower number of branches plant ${ }^{-1}$ (Ratan- 4.77, Opurba- 5.77) was noticed in the untreated control plot (Table 2). The results indicated that different treatment possessed the ability to increase the number of branches plant ${ }^{-1}$ by reducing the 
number of insect vector responsible for virus transmission. This virus infection was reduced and number of branches plant ${ }^{-1}$ was increased in healthy plant.

\section{Effects of different treatments on number of fruits plant ${ }^{-1}$}

The number of fruits plant $^{-1}$ was significantly increased due to different treatments compared to untreated control. The number of fruits was increased up to 24.89 (Ratan) and 18.00 (Opurba) by the application of different treatment while number of fruits was 17.89 (Ratan) and 11.00 (Opurba) in untreated control plot in the $1^{\text {st }}$ year trial (Table 3). The treated plots gave increased number of fruits plant ${ }^{-1}$ showing 13.78 to 17.34 (Ratan) and 13.43 to 17.24 (Opurba) in the $2^{\text {nd }}$ year trial. The inferior number of fruits plant $^{-1}$ was noticed in the untreated control (Table 3). The results indicated that different treatment possessed the ability to increased number of fruits plant ${ }^{-1}$ by reducing the number of insect vector responsible for virus transmission. This virus infection was reduced and number of fruits plant ${ }^{-1}$ was increased in healthy plant.

Table 2. Effect of variety and treatment on plant height and number of branches plant $^{-1}$ of tomato

\begin{tabular}{|c|c|c|c|c|}
\hline \multirow{2}{*}{ Variety x Treatment } & \multicolumn{2}{|c|}{ Plant height $(\mathrm{cm})$} & \multicolumn{2}{|c|}{$\begin{array}{c}\text { Number of branches } \\
\text { plant }^{-1}\end{array}$} \\
\hline & $1^{\text {st }}$ year & $2^{\text {nd }}$ year & $1^{\text {st }}$ year & $2^{\text {nd }}$ year \\
\hline Ratan x Uprooting & $53.00 \mathrm{de}$ & 82.47 cde & $5.00 \mathrm{ef}$ & $5.21 \mathrm{ef}$ \\
\hline Ratan x Admire (0.05\%) & $55.00 \mathrm{~d}$ & 87.47 a-e & $5.67 b-f$ & $5.77 \mathrm{c}-\mathrm{f}$ \\
\hline Ratan x Admire $(0.05 \%)$ on Marigold & $50.33 \mathrm{def}$ & $83.60 \mathrm{~b}-\mathrm{e}$ & $5.53 \mathrm{c}-\mathrm{f}$ & $4.88 \mathrm{f}$ \\
\hline Ratan x Neem oil $(0.5 \%)$ & $53.67 \mathrm{de}$ & 84.37 b-e & $5.53 \mathrm{c}-\mathrm{f}$ & $5.66 \mathrm{c}-\mathrm{f}$ \\
\hline Ratan x Sesame oil (0.5\%) & $49.00 \mathrm{ef}$ & $83.33 \mathrm{~b}-\mathrm{e}$ & $5.33 \mathrm{def}$ & $5.55 \mathrm{def}$ \\
\hline Ratan x Mustard oil (0.5\%) & 53.00de & 82.73 cde & $5.43 \mathrm{def}$ & $5.66 \mathrm{c}-\mathrm{f}$ \\
\hline Ratan $x$ control & $46.33 \mathrm{f}$ & $73.93 \mathrm{e}$ & $4.87 \mathrm{f}$ & $4.77 \mathrm{f}$ \\
\hline Opurba x Uprooting & $86.33 \mathrm{c}$ & $95.60 \mathrm{a}-\mathrm{d}$ & $5.63 \mathrm{~b}-\mathrm{f}$ & $6.55 \mathrm{bcd}$ \\
\hline Opurba x Admire (0.05\%) & $96.00 \mathrm{ab}$ & $102.9 \mathrm{a}$ & $7.43 \mathrm{a}$ & $7.88 \mathrm{a}$ \\
\hline Opurba x Admire $(0.05 \%)$ on Marigold & $91.33 b c$ & 85.00 be & $5.80 \mathrm{~b}-\mathrm{f}$ & $6.88 \mathrm{abc}$ \\
\hline Opurba x Neem oil (0.5\%) & $95.67 \mathrm{ab}$ & $99.13 \mathrm{abc}$ & $6.63 \mathrm{abc}$ & $7.44 \mathrm{ab}$ \\
\hline Opurba x Sesame oil $(0.5 \%)$ & $86.67 \mathrm{c}$ & $99.67 \mathrm{ab}$ & $5.90 \mathrm{~b}-\mathrm{f}$ & $7.44 \mathrm{ab}$ \\
\hline Opurba x Mustard oil (0.5\%) & $93.67 \mathrm{ab}$ & 97.87 a-d & $6.43 a-d$ & $6.33 \mathrm{~b}-\mathrm{e}$ \\
\hline Opurba x control & $86.00 \mathrm{c}$ & $81.40 \mathrm{~d} \mathrm{e}$ & $6.10 \mathrm{~b}-\mathrm{e}$ & $5.77 \mathrm{c}-\mathrm{f}$ \\
\hline $\mathrm{CV}(\%)$ & 13.19 & 14.43 & 10.70 & 10.68 \\
\hline
\end{tabular}

In a column, similar letter (s) do not differ significantly by DMRT at 5\% level of probability, 1st year $=2009$ and 2 nd year $=2010$. 


\section{Effect of variety and treatment on tomato yield}

The yield of tomato was increased significantly in different levels due to different treatments through suppressing aphid population and exclusion of virus infection. In the 1st year experiment, yield of tomato was ranged from 37.83 to $47.70 \mathrm{t} \mathrm{ha}^{-1}$ (Ratan) and 15.12 to $23.18 \mathrm{t} \mathrm{ha}^{-1}$ (Opurba) among treated plots which were minimum (Ratan-32.6, Opurba-14.15 $\mathrm{t} \mathrm{ha}^{-1}$ ) in the untreated control plot (Table 3). Similarly, the yield of tomato varied from 35.64 to $52.36 \mathrm{t} \mathrm{ha}^{-1}$ (Ratan) and 35.78 to $50.03 \mathrm{t} \mathrm{ha}^{-1}$ (Opurba) in the second year experiment due to spraying insecticide, applying cultural and oil treatments for suppressing whitefly and subsequently reducing virus infection (Table 3). Minimum yield of $32.95 \mathrm{t} \mathrm{ha}^{-1}$ (Ratan) and $30.30 \mathrm{t} \mathrm{ha}^{-1}$ (Opurba) was recorded from the untreated control plots in the $2^{\text {nd }}$ year trials. Among the treatments admire sprayed plot gave higher yield, followed by neem oil and admire sprayed on trap crop (marigold) (Table 3 ). This higher yield was due to suppressing whitefly population and subsequently reducing TYLCV infection.

Table 3. Effect of variety and treatment on number of fruits plant $^{-1}$ and yield of tomato

\begin{tabular}{l|c|c|c|c}
\hline \multirow{2}{*}{\multicolumn{1}{c}{ Variety x Treatment }} & \multicolumn{2}{c|}{$\begin{array}{c}\text { Number of fruits } \\
\text { plant }\end{array}$} & \multicolumn{2}{c}{ Yield (t ha $\left.{ }^{-1}\right)$} \\
\cline { 2 - 5 } & $1^{\text {st }}$ year & $2^{\text {nd }}$ year & $1^{\text {st }}$ year & $2^{\text {nd }}$ year \\
\hline Ratan x Uprooting & $20.22 \mathrm{bc}$ & $13.84 \mathrm{~cd}$ & $40.38 \mathrm{~b}$ & $35.64 \mathrm{de}$ \\
Ratan x Admire $(0.05 \%)$ & $24.89 \mathrm{a}$ & $17.34 \mathrm{a}$ & $47.7 \mathrm{a}$ & $52.36 \mathrm{a}$ \\
Ratan x Admire $(0.05 \%)$ on Marigold & $21.33 \mathrm{~d}$ & $13.78 \mathrm{~cd}$ & $38.61 \mathrm{~b}$ & $34.94 \mathrm{de}$ \\
Ratan x Neem oil $(0.5 \%)$ & $22.89 \mathrm{ab}$ & $17.00 \mathrm{ab}$ & $42.61 \mathrm{~b}$ & $50.33 \mathrm{a}$ \\
Ratan x Sesame oil $(0.5 \%)$ & $16.89 \mathrm{de}$ & $14.29 \mathrm{bcd}$ & $37.83 \mathrm{~b}$ & $37.40 \mathrm{cde}$ \\
Ratan x Mustard oil (0.5\%) & $22.56 \mathrm{ab}$ & $16.47 \mathrm{abc}$ & $37.91 \mathrm{~b}$ & $46.12 \mathrm{abc}$ \\
Ratan x control & $17.89 \mathrm{~cd}$ & $11.80 \mathrm{e}$ & $32.6 \mathrm{c}$ & $32.95 \mathrm{e}$ \\
Opurba x Uprooting & $16.33 \mathrm{def}$ & $13.47 \mathrm{de}$ & $20.65 \mathrm{de}$ & $35.78 \mathrm{de}$ \\
Opurba x Admire (0.05\%) & $18.00 \mathrm{~cd}$ & $17.24 \mathrm{a}$ & $23.18 \mathrm{~d}$ & $50.03 \mathrm{a}$ \\
Opurba x Admire(0.05\%) on Marigold & $16.33 \mathrm{def}$ & $13.65 \mathrm{~cd}$ & $22.37 \mathrm{~d}$ & $39.91 \mathrm{cde}$ \\
Opurba x Neem oil (0.5\%) & $17.22 \mathrm{~d}$ & $16.53 \mathrm{abc}$ & $20 \mathrm{de}$ & $49.08 \mathrm{ab}$ \\
Opurba x Sesame oil (0.5\%) & $13.44 \mathrm{fg}$ & $15.53 \mathrm{a}-\mathrm{d}$ & $15.21 \mathrm{f}$ & $44.75 \mathrm{a}-\mathrm{d}$ \\
Opurba x Mustard oil (0.5\%) & $15.33 \mathrm{gef}$ & $13.43 \mathrm{de}$ & $16.49 \mathrm{ef}$ & $37.23 \mathrm{cde}$ \\
Opurba x control & $11.00 \mathrm{~g}$ & $10.94 \mathrm{e}$ & $14.75 \mathrm{f}$ & $30.30 \mathrm{e}$ \\
CV(\%) & 14.06 & 10.40 & 9.76 & 12.74 \\
\hline
\end{tabular}

In a column, similar letter (s) do not differ significantly by DMRT at 5\% level of probability, 1 st year $=2009$ and 2 nd year $=2010$. 


\section{Relationship between number of whitefly population and $\%$ virus infection}

Correlation and regression analysis was performed to find out the relationship between numbers of whitefly population with \% virus infection of tomato. A positive correlation between number of whitefly population and \% virus infection was observed in both the years (Fig. 1). The relationship between number of whitefly population and \% virus infection could be expressed by the equation $\mathrm{y}=0.4217 \mathrm{x}+4.7954, \quad\left(\mathrm{R}^{2}=0.2016\right) \quad$ and $\mathrm{y}=0.8036 \mathrm{x}+0.0917, \quad\left(\mathrm{R}^{2}=0.5304\right)$, respectively, where $\mathrm{x}=$ number of whitefly population and $\mathrm{y}=\%$ virus infection. Here, the $\mathrm{R}^{2}$ value indicates the contribution of number of whitefly population to the $\%$ viral infection of tomato.

\section{Relationship between $\%$ virus infection and number of fruits plant ${ }^{-1}$}

A negative correlation between $\%$ virus infections with number of fruits plant ${ }^{-1}$ was observed in both the years (Fig. 2). The relationship between $\%$ virus infection and number of fruits plant ${ }^{-1}$ could be expressed by the equation $\mathrm{y}=-$ $0.6171 \mathrm{x}+23.337, \quad\left(\mathrm{R}^{2}=0.3976\right) \quad$ and $\mathrm{y}=-0.3371 \mathrm{x}+16.998, \quad\left(\mathrm{R}^{2}=0.5785\right)$, respectively, where $x=\%$ virus infection and $y=$ number of fruits plant $^{-1}$. Here, the $\mathrm{R}^{2}$ value indicates the contribution of $\%$ virus infection to the number of fruits plant ${ }^{-1}$ of tomato.

\section{Relationship between $\%$ virus infection and yield $\left(\mathrm{t} \mathrm{ha}^{-1}\right)$}

A negative correlation between $\%$ virus infections with yield $\left(\mathrm{t} \mathrm{ha}^{-1}\right)$ was observed in both the years (Fig. 3). The relationship between \% virus infection and yield $\left(\mathrm{t} \mathrm{ha}^{-1}\right)$ could be expressed by the equation $\mathrm{y}=-1.0817 \mathrm{x}+38.371$, $\left(\mathrm{R}^{2}=0.1378\right)$ and $\mathrm{y}=-1.0458 \mathrm{x}+48.441,\left(\mathrm{R}^{2}=0.4309\right)$, where $\mathrm{x}=\%$ virus infection and $\mathrm{y}=$ yield $\left(\mathrm{t} \mathrm{ha}^{-1}\right)$. Here, the $\mathrm{R}^{2}$ value indicates that the contribution of $\%$ virus infection to the plant height of tomato.

\section{B. Discussion}

The use of insecticides and oils to reduce virus transmission by whiteflies has yielded more or less satisfactory results in a limited number of cases. Cultural control measures to reduce the disease incidence consisted sanitation, mixed of cropping, physical barriers and cultivation of resistant varieties. Many systemic and contact insecticides have been tested for control of whiteflies, but few gave effective control. Admire was found to be effective in reducing TYLCV incidence and resulted yield increase. The results are in agreement with the findings of Savary (2000) and Ahmed et al. (2001). Imidacloprid (a systemic chloronicotinyl insecticide, Admire) gained major importance for controlling Bemisia tabaci in both field and protected crops, in view of extensive resistance 

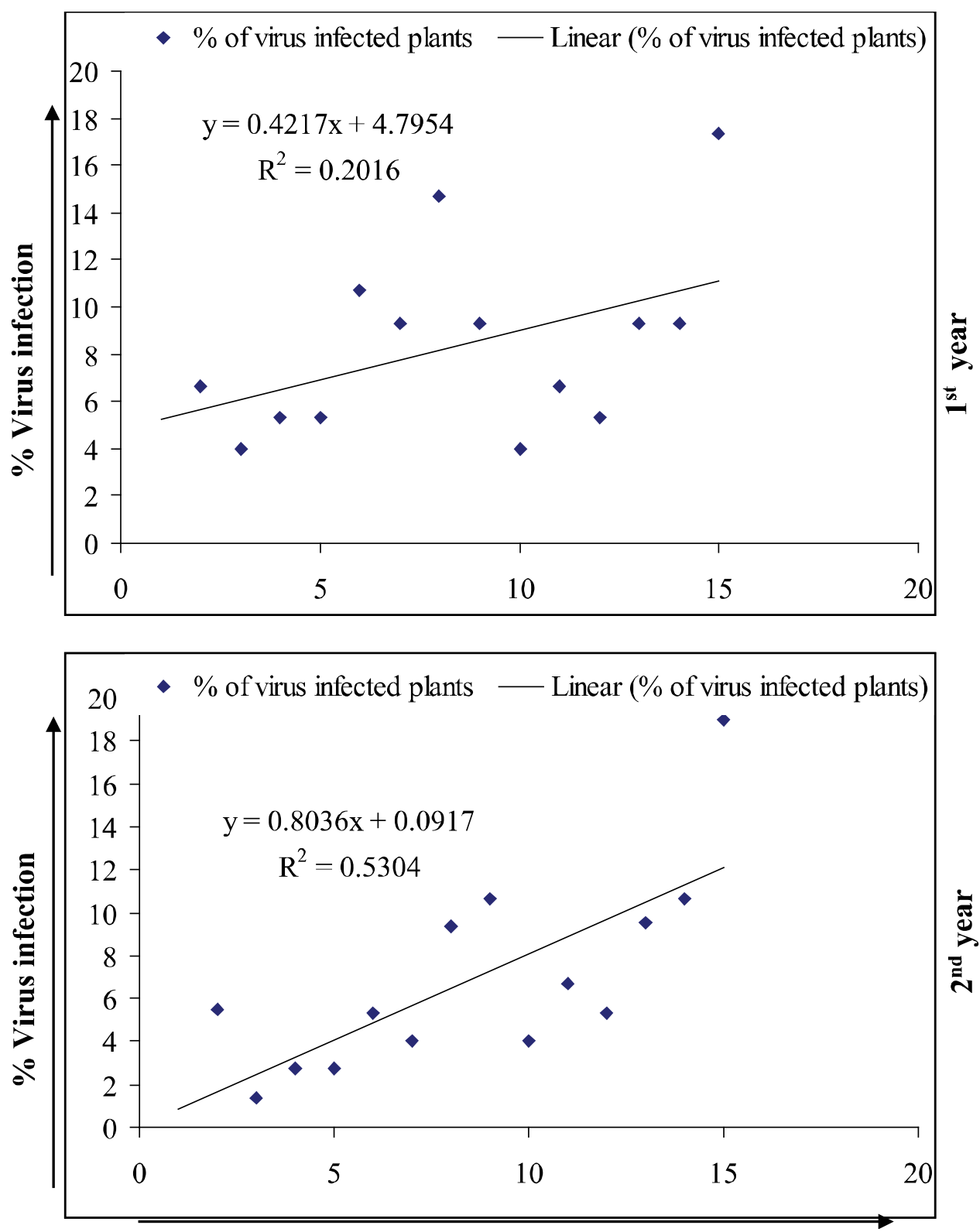

Fig. 1. Relationship between number of whitefly population and \% virus infection. A positive correlation was observed between white fly population and \% TYLCV infection for both the years. The relationship was linear and positive for number of whitefly population and \% virus infection of tomato with coefficient of correlations $(r) \quad 0.4489$ and 0.7282 , respectively. The relationship was significant and may be attributed to $20.16 \%\left(R^{2}=0.2016\right)$ and $53.04 \%\left(R^{2}=\mathbf{0 . 5 3 0 4}\right)$, respectively. 

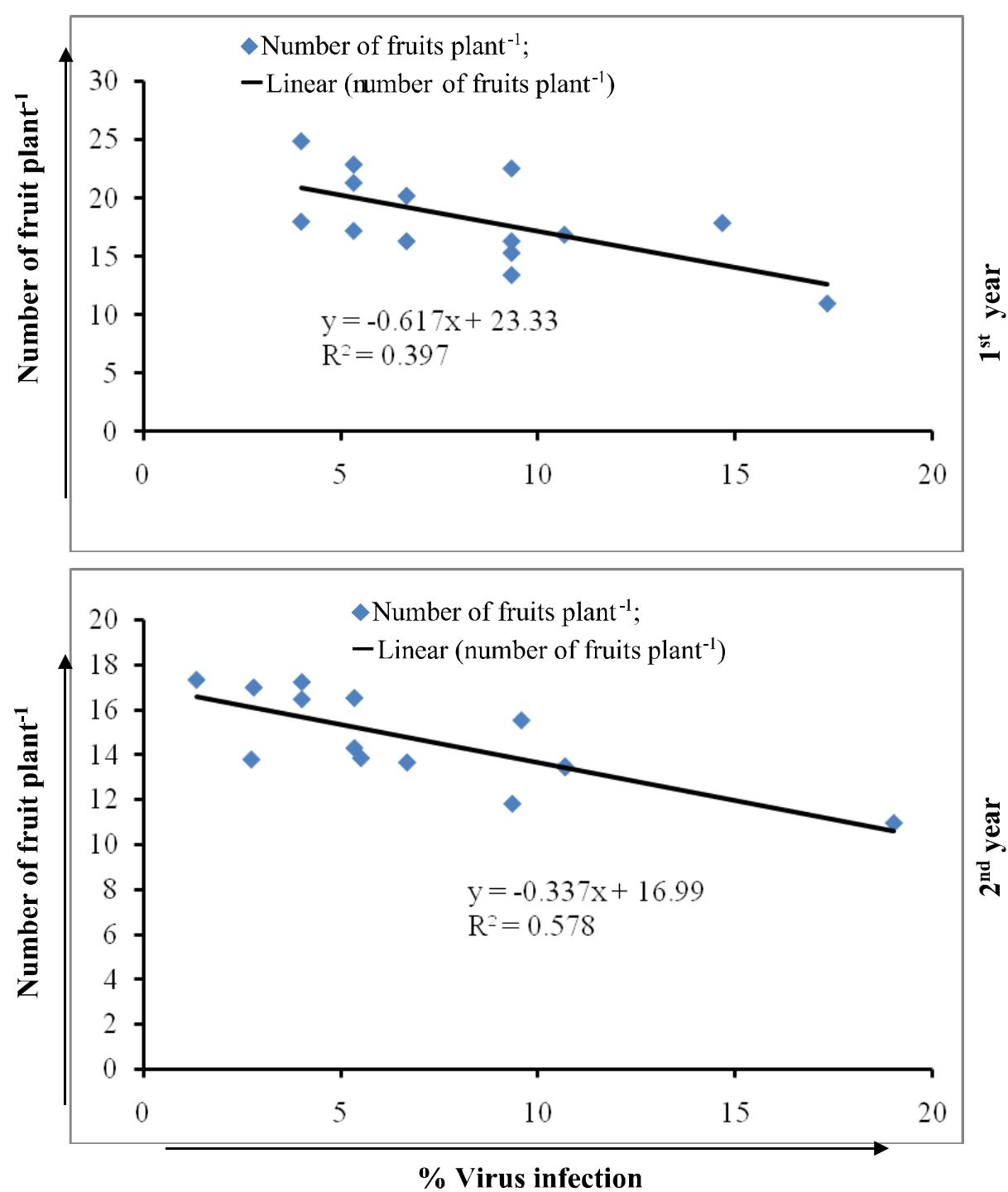

Fig. 2. Relationship between $\%$ virus infection and number of fruits plant ${ }^{-1}$. A negative correlation was observed between \% TYLCV infection and number of fruits/plant for both the years. The relationship was linear and positive for $\%$ TYLCV infection and number of fruits plant ${ }^{-1}$ of tomato with coefficient of correlations was (r) 0.6305 and 0.7605 , respectively. The relationship was significant and may be attributed to $20.16 \%\left(\mathbf{R}^{2}=0.3976\right)$ and $53.04 \%\left(\mathbf{R}^{2}=\right.$ 0.5785), respectively.

to Organophosphorous, Pyrethroid and Cyclodiene insecticides (Cahil et al., 1995). Admire is currently recommended for the control of whitefly in many countries including the USA. Whiteflies are known to develop resistance against 
pesticides within a few years of application. Until now there is no report on resistance of whitefly against Admire. Spraying a tomato with Admire, which is a broad- spectrum and systemic insecticide, is similar to the situation in Bangladesh farmers' fields, where continuous application of various insecticides takes place. A spray with Admire performed worse than the control plot. Continuous application of such insecticides may be leading to eradication of natural enemies of whitefly (Henneberry and Castle, 2001; Riley et al., 1995; Duffus, 1995). Uprooting alone gave better results than where Admire was applied without uprooting diseased plants. Uprooting is a better option if farmers are to manage TYLCV disease, avoid destroying natural enemies of whitefly. Therefore, future studies need to focus on identifying natural enemies of whitefly and designing environment-friendly whitefly control methods such as use of virus resistant tomato varieties, use of mulches, and uprooting infected tomato plants.

Oil spray can reduce white fly population and was effective against incidence of TYLCV is well documented in the review by Green and Kalloo (1994). Oils seem to create a film around the surface of the sprayed area which creates problem for probing by insects. Butler et al. (1991) conducted a study to assess several plant derived oils to control sweet potato whitefly (Bemisia tabaci) in tomato. House hold cooking oils like corn, peanut, safflower; soybean and sunflower oils were usually used as $1 \%$ foliar spray. Oil spray significantly reduced whitefly adults and immatures for 5 days as compared to control. For home gardeners use of cooking oils and liquid detergents available in most homes is recommended as a safe and economic solution for the control of whitefly. However effectiveness of oils depend on several parameters like type of oil, choice of emulsifier, type of spray nozzle and pressure (Sastry, 1989 and Tomlinson, 1987).

Our study considered several factors involved in influencing whitefly transmission of TYLCV, it is suggested that a system wise approach for studying tomato yellow leaf curl viruses be applied in future studies on this subject. As observed during the present study, uprooting, intercropping, oil spray and use of Admire insecticide suppress whitefly populations, and hence reduce TYLCV disease incidence.

It may be concluded that the treatments reduced TYLCV disease and increased tomato yield. The findings of the present study are in agreement with Kumar et al. (2005); Hilje et al. (2001); Palumbo et al. (2001); Csizinsky et al. (1997) and Sastry, (1989) who also found that uprooting, application of oils and insecticides had some positive impact on disease reduction and yield increase. Among the tested oils, neem was found as the best to reduce the TYLCV disease incidence 
of tomato and there by produced higher yield. However, mustard and sesame oils may be applied to manage TYLCV disease infecting tomato.
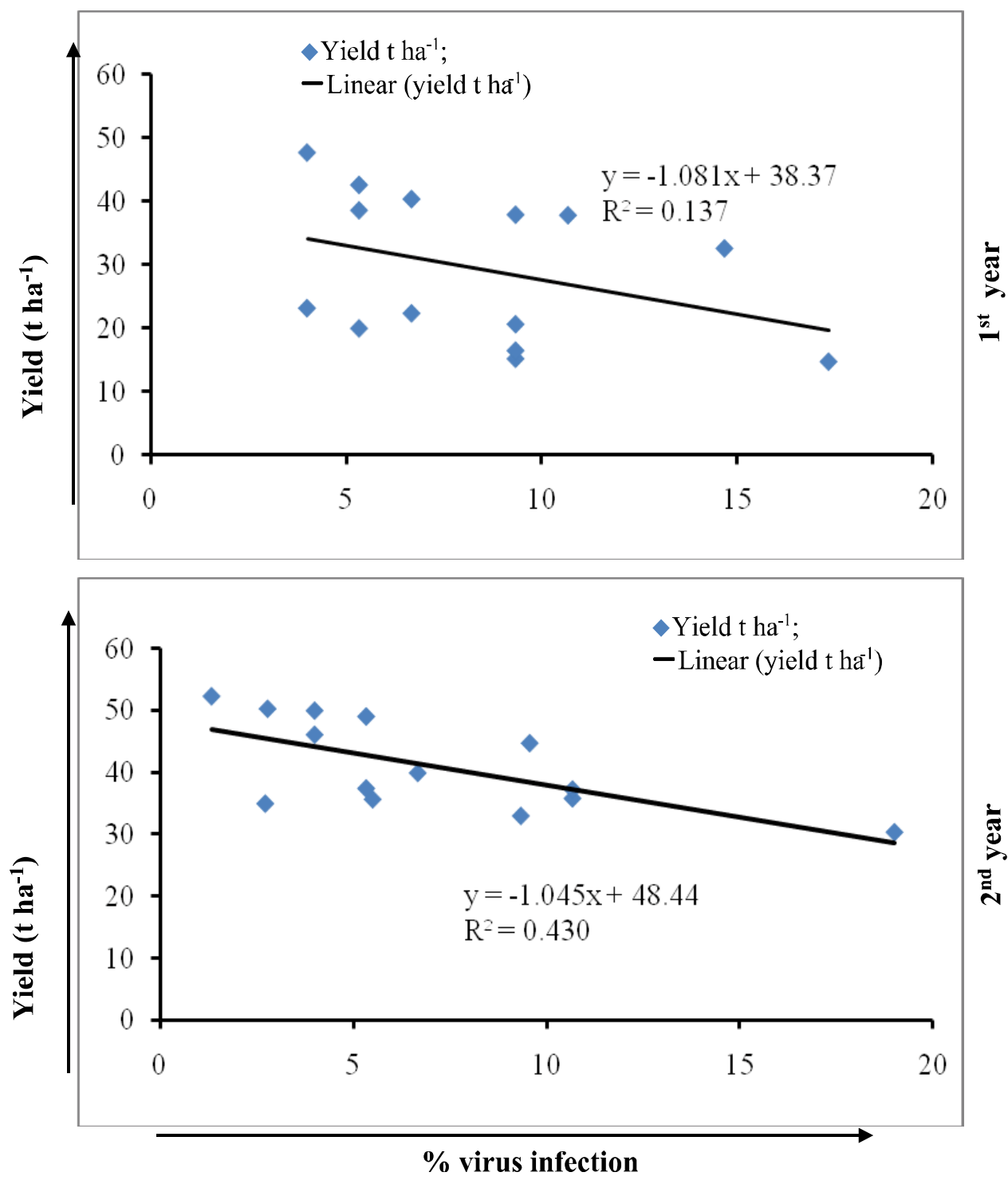

Fig. 3. Relationship between $\%$ virus infection and yield $\left(t\right.$ ha $\left.^{-1}\right)$. A negative correlation was observed between \% TYLCV infection and yield (t ha-1) for both years. The relationship was linear and positive for \% TYLCV infection and yield (t ha-1) of tomato with coefficient of correlations was (r) 0.3712 and 0.6564 , respectively. The relationship was significant and may be attributed to $20.16 \%\left(R^{2}=0.1378\right)$ and $53.04 \%\left(R^{2}=0.4309\right)$, respectively. 


\section{References}

Ahmed, N. E., H. O. Kanan, Y. Sugimoto, Y. Q. Ma, and S. Inanaga. 2001. Effect of Imidacloprid on incidence of Tomato yellow leaf curl virus. Plant Disease. 85:84-87.

Butler, G. D. J. and T. J. Henneberry. 1991. Sweet potato whitefly control: Effect of tomato cultivars and plant derived oils. Southwestern Entomologist. 16(1):37-43.

Brown, J. K. and J. Bird. 1995. Introduction of an exotic whitefly (Bemisia) vector facilitates secondary spread of Jatropha mosaic virus, a Geminivirus previously vectored exclusively by the "Jatropha" biotype. In: Gerling, D. and R. T. Mayer (eds), Bemisia 1995: Taxonomy, Biology, Damage, Control and Management. Intercept, Andover, U.K. 351-353.

Cahil, M., F. J. Byrne, K. Gorman, I. Denholm and A. L. Devonshire. 1995. Pyrethroid and Organophosphate resistance in tobacco Whitefly, Bemisia tabaci (Homoptera: Alerodidae). Bulletin on Entomological Research. 85:181-187.

Csizinsky, A. A., D. J. Schuster and J. B. Kring. 1997. Evaluation of colour mulches and oil spray for yield and for the control of silver leaf whitefly, Bemisia argentifilii (Bellows and Perring) on tomatoes. Crop Protection. 16(5): 475-481.

Duffus, J. E. 1995. Whitefly borne viruses in (Gerling D. and R. T. Mayer) Bemisia: 1995 Taxonomy, Biology, Damage, Control and Mangement. 255 - 263.

Green, S. K. and G. Kalloo. 1994. Leaf curl and yellowing viruses of pepper and tomato: an overview. Technical Bulletin No. 21. Asian Vegetable Research and Development Center, Taiwan. 51p.

Gupta, N. D. 2000. Occurrence of Tomato yellow leaf curl virus (TYLCV) and Tomato purple vein virus (TPVV) and their effect on growth and yield of tomato. An MS thesis submitted to Department of Plant Pathology, BSMRAU, Salna, Gazipur, 77p.

Henneberry, T. J. and S. J. Castle. 2001. Bemisia: Pest Status, Economics, Biology, and Population Dynamics, pp. 247-278 Chapter 13. In K. Harris [ed.] Virus-InsectPlant-Interactions, Academic Press, N. Y.

Hilje, L., H. S. Costa, and P. A. Stansly. 2001. Cultural practices for managing Bemisia tabaci and associated viral diseases. Crop Protection. 20: 801-812.

Hirano, K., E. Budiynto and S. Winarni. 1993. Biological characteristics and forecasting outbreaks of the whitefly Bemisia tabaci, a vector of virus diseases in soybean fields. Food and Fertilizer Technical bulletin. No.135. 14p.

Kumar, P., H. M. Poehling, and C. Borgemeister. 2005. Effects of different application methods of azadirachtin against sweetpotato whitefly Bemisia tabaci Gennadius (Homoptera, Aleyrodidae) on tomato plants. J. Applied Ent. 129: 9-10.

Lapidot, M., M. Friedmann, M. Pilowsky, R. Ben-Joseph and S. Cohen. 2001. The effect of host resistance on Tomato yellow leaf curl virus (TYLCV) on virus acquisition and transmission by its whitefly vector. Phytopathology. 91: 1209-1213. 
Mead, R. and R. N. Curnow. 1990. Statistical methods in Agriculture and Experimental Biology 3rd Edition Chapman and Hall, London, $333 \mathrm{Pp}$.

Mondal, M. R. I, M. K. Sultan, S. Nur, M. Z. U. Sarkar, M. S. Alam and M. H. H. Rahman. 2014. Krishi Projuckti Hatboi (Handbook on Agro-technology), $6^{\text {th }}$ edition. Bangladesh Agricultural Research Institute. Gazipur 1701, Bangladesh, Pp 403-409.

Palumbo, J. C., A. R. Horowitz and N. Prabhaker. 2001. Insecticidal control and resistance management for Bemisia tabaci. Crop Protection. 20: 739-765.

Polston, J.E., R.J. McGovern and L.G. Brown. 1999. Introduction of Tomato yellow leaf curl virus in Florida and implications for the spread of this and other geminiviruses of tomato. Plant Disease. 83:984-988.

Polston, J. E., L. Cohen, T. A. Sherwood, R. B. Joseph and M. Lapidot. 2006. Capsicum species: symptomless hosts and reservoirs of Tomato yellow leaf curl virus. Phytopathology. 96: 447-452.

Raccah, B. 1986. Non-persistent viruses: Epidemiology and control. Advances in Virus Research. 31: 387- 429.

Riley, D., U. Nava - Camberos and J. Allen. 1995. Population dynamics of Bemisia in agricultural systems, in Bemisia 1995: Taxonomy, Biology, Damage, Control and Management (Gerling, D. and R.T. Mayer), 288 P.

Sastry, S. K. 1989. Tomato leaf curl virus management by Carbofuran plus oils combination. Journal of Turkish Phytopathology. 18(1-2): 11-16.

Savary, P. 2000. Effect of whitefly control on Tomato yellow leaf curl virus incidence for fresh market tomato. ARC-AVRDC Training Report 2000. (http: www.arcavrdc.org/ pdf_files/027-savary-18th. Pdf). 205p.

Sinistera, X., C. P. Patte, S. Siewnath, and J. E. Polston. 2000. Identification of Tomato yellow leaf curl virus-is in the Bahamas. Plant Disease. 84(5): 592.

Tomlinson, J. A. 1987. Epidemiology and Control of virus diseases of vegetables. Annual Applied Biology. 110:661-681.

Varela, A. M. 1995. Major pests of tomatoes in eastern and southern Africa: Compilation of past research work and identification of IPM opportunities. GTZ-IPM Horticulture Project Consultancy Report, Nairobi, Kenya. 32p. 